\title{
Policing Protest in the Austerity-driven Slovenia ${ }^{1}$
}

\begin{abstract}
This article aims to evaluate protest policing in the austerity-driven Slovenia and verify the analytical effectiveness of a tool for measuring protest policing. Therefore, the paper critically discusses and modifies Donatella della Porta and Herbert Reiter's theoretical framework consisting of the escalated force and negotiated management antinomic ideal types, and then applies it to examine the Slovenian case. The research draws on a qualitative method of sources analysis based on a conceptual qualitative content analysis to solve the problems of what was the Slovenian model of protest policing in times of austerity? And why did it have a particular shape? The study diagnoses Slovenia as having the negotiated management mode of protest policing with the elements of the escalated force model. This mode stems from the organizational dynamics of the Slovenian National Police which typifies with the dialectic of decentralization and hierarchical submission in police units, the effectively used possibilities to coordinate the different groups operating within protesting crowds, and certainty about the purposes of the intervention.
\end{abstract}

Key words: protest policing, culture of political violence, Slovenian National Police, protest movement, political demonstration

\section{Introduction and Methodological Assumptions for the Research}

n 2012-2013, numerous angry anti-austerity events strongly influenced public order and security in individual parts of Slovenia. Their common characteristic was that the organizer was anonymous since the calls for protests were made with the electronic communication devices by a leaderless All-Slovenian Popular Uprising. Political demonstrations were registered rarely, the place and the beginning of the event were usually known but the number of participants and their structure remained unknown until its completion. Because of these circumstances, the effective protection of life, personal safety, property, and the provision of a constitutional right to the peaceful gathering (Policija, 2013) posed a challenge to the Slovenian National Police.

Noteworthy, the modes of responding to this challenge are still an uncovered issue in the specialist literature while their critical evaluation and understating may contribute to the recognition of the dynamics of relationships between subjects in political structures and a practical improvement of protest policing in democratic states.

${ }^{1}$ This paper is a result of the research project The Culture of Political Violence Dynamics of Antiausterity Movements in Europe. It was financially supported by the National Science Centre, Poland [grant number 2016/23/D/HS5/00192].

I acknowledge doctor Džemal Durić (višji policijski inšpektor GPU I) and Danijel Žibret (direktor višji policijski svetnik) for their invaluable professional help with discovering Slovenian protest policing and providing data necessary to conduct the research. 
Current works on social mobilization in the austerity-driven Slovenia concentrate on the protest movement rather than either the police or the relations between the political subjects engaged in anti-austerity events (Rak, 2017; 2018b). Although they make a considerable contribution to our knowledge of why the anti-austerity movement emerged (Razsa, Kurnik, 2012), how the idea of its continuance spread (Flesher Fominaya, 2017), and why the protest was relatively unique while comparing it with predecessors (Krašovec, 2013; Toplišek, Thomassen, 2017; Perković, Učakar, 2017), they tell little about how the police dealt with event participants, why they operated this way, and thus how the political subjects created one of the most violent cultures of political violence in the austerity-driven Eurozone.

The overall aim of the article is to give insight into the processes of public interaction between the police and political protesters in times of austerity by evaluating the mechanisms of protest policing. Its secondary goal is to verify the analytical effectiveness of a research tool for measuring protest policing. Therefore, the paper critically discusses and modifies Donatella della Porta and Herbert Reiter's theoretical framework, and then applies its new version to examine the Slovenian case. The new analytical approach differs from the original one in the semantic fields of indicators, their extreme values, and offers their operationalized definitions.

This article adopts a relational approach to solve the research problems of what was the Slovenian model of protest policing in times of austerity? And why did it have a particular shape? It formulates the theory-driven hypotheses (della Porta, Reiter, 1998, p. 21; Whelan, 2017; Millen, Stephens, 2011) that the Slovenian model of protest policing most likely is between the antinomic ideal types of escalated force and negotiated management close to the latter. Additionally, its shape might derive from the organizational dynamics of the Slovenian National Police which typifies with the dialectic of decentralization and hierarchical submission in police units, the effectively used possibilities to coordinate the different groups operating within protesting crowds, and certainty about the aims of the intervention (della Porta, Reiter, 1998, p. 21).

The analysis involves the research field determined by the activities undertaken by the Slovenian National Police in relation to the anti-austerity movement that acted in times of austerity between November 2, 2012 and December 31, 2013 in Slovenia on the area of all the police units: Celje, Koper, Kranj, Ljubljana, Maribor, Murska Sobota, Nova Gorica, and Novo Mesto. November 2, 2012 is the initial caesura of the research field because then the Slovenian anti-austerity movement emerged out of opposition to the austerity measures imposed by the European Union and the government, dissatisfaction with political and economic elites, corruption, social inequality, and concern for prospective social security (Durić, Žibret, 2017; Policija, 2013; Rak, 2018a). The closing caesura is December 31,2013, the end of the last protest, when the great wave of antiausterity events (Policija, 2013) ceased in Slovenia.

This research field is explored by using a qualitative method of sources analysis. A conceptual qualitative content analysis allows us to collect the pieces of data sufficient and necessary to solve the research problems. The data comes from various sources because there is no comprehensive and credible database which encompasses crucial information on protest policing in Slovenia. Furthermore, the researcher avoids following one discourse created either by the protesters and media or the police. So, the 
analysis draws on the Slovenian National Police's report "Analiza aktivnosti policije ob protestih na območju Republike Slovenije" (Policija, 2013) (in English: "Activities of the Police over the Protests in the Republic of Slovenia"), articles, and visual materials published in Slovenian and international, public, commercial, and social media. The main criterion for sources selection is their utility to test the hypotheses effectively. Hence, the whole process of collecting data is purpose-driven primarily. According to the principle of theoretical sampling, the theoretical developments that occurred in an analysis of the previously gathered data lead the following stages of data collection. The cycle of alternation between data collection and analysis does not stop at two repetitions but stands until theoretical saturation is attained. Thereby, it lasts pending the new pieces of data are introducing the exemplifications of new theoretical elements and finishes when they are confirming what has already been discovered (Punch, 2014, p. 134). The sources triangulation strives to generate as reliable data as possible. The research tools are a theoretical framework of protest policing and the questionnaire for content analysis which covers the essential features of the models and their values. The next parts of the article introduce and apply the device as well as address the research problems.

\section{The Theoretical Framework for Analyzing Protest Policing}

Della Porta and Reiter's theoretical framework for scrutinizing protest policing consists of the nine indicators whose extreme values are the essential features of the models of escalated force and negotiated management respectively (della Porta, Reiter, 1998, p. 7): (i) "brutal" versus "soft" referring to the degree of force used, (ii) repressive versus tolerant referring to the number of prohibited behaviors, the extent of conduct regarded as illegitimate, (iii) diffused versus selective referring to the number of repressed groups, (iv) illegal versus legal referring to police respect for the law, (v) reactive versus pre-emptive/preventive referring to the moment when police act, (vi) confrontational versus consensual, referring to the degree of communication with the demonstrators, (vii) rigid versus flexible referring to the degree of "adaptability," capacity to adjust to emerging situations, (viii) informal versus formal referring to the degree of formalization of the rules of the game, and (ix) artisanal/improvised versus professional referring to the degree of "preparation", i.e., training (della Porta, Reiter, 1998, p. 4; 2006, p. 13). According to the authors, in the escalated force model, police give low priority to the right to demonstrate: innovative forms of protest are poorly tolerated, communication between police and participants of protests is reduced to essentials, there is frequent employment of coercive or even illegal methods (e.g., agents provocateurs), police officers improvise, act reactively, rigidly, and rules of the game are informal. In the negotiated management model, by contrast, police prioritize the right to hold protest peacefully, even disruptive forms of protest are tolerated, communication between protesters and police is considered basic to the peaceful conduct of protest, and coercive means are avoided as much as possible, highlighting selectivity of operations, police officers fully adjust to emerging situation, act preventively, are professional, and the rules of the game are formal (della Porta, Reiter, 2006, p. 13). 
Nevertheless, the analytical effectiveness of the framework may be limited by its methodological drawbacks. The indicators and their values are not defined and operationalized. Additionally, some of them contain minor inadequacies, e.g., the indicators of the number of prohibited behaviors and police respect for the law have parts of their semantic fields in common and thus refer to the same things while they should explore different aspects of protest policing. This paper attempts to eliminate these flaws to create an effective research tool.

The first indicator refers to the degree of force used by policemen to police protest and has two extreme values: "brutal" and "soft" (della Porta, Reiter, 1998, p. 4). The new approach draws upon della Porta and Reiter's indicator, but it narrows the semantic field of force, which may be both mental and physical, down to physical violence (Finlay, 2017, p. 72), and it adopts the extent of the intensity of physical violence as a criterion for distinguishing the models of protest policing. In the escalated force model, police employ maximally intense physical force. Not only are protesters wounded but also killed. In the negotiated management model, police completely abandon using both active and passive physical violence (threat).

The next indicator is of quantitative nature since it concentrates on the number of prohibited behaviors. It takes up the values of repressiveness and tolerance for the escalated force and negotiated management models respectively (della Porta, Reiter, 1998, p. 4). According to this approach, a behavior regarded as illegitimate is prohibited (della Porta, Reiter, 2006, p. 13). The reference to the imprecisely conceptualized act of "regarding" leads us to the questions about who or what determines the extent of a public role and what a legitimizing factor is. In its current shape, the indicator of the prohibited behaviors may have a part of its semantic field in common with the fourth indicator that distinguishes between illegal and legal protest policing by referring to police respect for the law. The new approach formulates the two indicators of the type of protest policing that deal with the category of prohibited behavior. First, the extent of legal legitimation of behavior points out if police officers act within the bounds of the law. If a behavior is within the legal rules established in a particular political structure, the negotiated management model occurs. Then, if it is not, the escalated force model emerges. Second, the extent of social legitimation of police behavior by participants of protest is under evaluation. The new approach does not follow the distinction between repressiveness and tolerance because they are not antinomic features and as such, they are useless as a homogenous criterion for differentiating between the antinomic models for one indicator. Protesters consider protest policing repressive and entirely unacceptable in the escalated force model. In turn, in the negotiated management model, it is perceived as non-coercive and fully acceptable. Importantly, these indicators are qualitative because they do not focus on how many times a behavior was illegitimate. Instead, they indicate if police officers crossed the line and then, if yes, what the extent of delegitimation of a behavior was.

Della Porta and Reiter propose one more quantitative indicator, a number of repressed groups. Yet its suggested extreme values are rather qualitative since protest policing may be either diffused or selective according to the authors (della Porta, Reiter, 1998, p. 4). These categories are not defined and operationalized, so their applicability is relatively broad. In the new approach, the indicator addresses apprehension of protesters. In the 
escalated force model, all protesters are punished by arrest for taking part in a protest. In the negotiated management model, none protester is arrested. A percentage of the arrested allows us to locate a case between these extreme types.

The timing of police action is the next indicator of a type of protest policing. It is preemptive/preventive for the negotiated management model and reactive for the escalated force model (della Porta, Reiter, 1998, p. 4). The theoretical approach created for this article adopts della Porta and Reiter's approach to the time when police act in its current form.

The sixth indicator concerns the degree of communication with demonstrators and may be confrontational or consensual (della Porta, Reiter, 1998, p. 4). Although the analysis of protest policing has to approach the quality of communication, the category of communication is too broad semantically to become an indicator. The new approach proposes the indicator of the ability to make an agreement. In the escalated force model, police do not pursue making an agreement but confronting with protesters. In the negotiated management model, police communicate with protesters to make a mutually acceptable deal.

The degree of "adaptability" understood as a capacity to adjust to emerging situations is the next indicator whose extremes are rigidity and flexibility (della Porta, Reiter, 1998, p. 4). Charles Tilly (2006, p. 44) and Takeshi Wada (2016, p. 449) developed this approach by specifying the semantic fields of the values taken up by the indicator. According to them, rigidity, typical of the escalated force model, appears when police use a single action form over and over again. The negotiated management model is distinguished by flexibility. It means a repertoire of action in which various forms are in use and previously employed forms do not predict the next (Wada, 2016, p. 449). The new approach accepts Tilly and Wada's set of values for the indicator of a capacity to adjust to emerging situations.

The degree of formalization of the rules of the game is an unspecified indicator. Della Porta and Reiter determine the scale for the formalization that ranges from informality to formality but do not conceptualize its values (della Porta, Reiter, 1998, p. 4). The new approach modifies the original framework of protest policing by replacing this feature with the indicator of predictability of police mode of conduct. In the escalated force model, police mode of conduct is unpredictable and thus protesters do not know how policemen will respond to base motives. At the other extreme, the negotiated management model, police mode of conduct is predictable on the basis of previous behavior and the upheld law.

The last indicator is the degree of "preparation," that is training, and takes up the values of artisanal/improvised and professional action (della Porta, Reiter, 1998, p. 4). The new approach considers it the extent of professionalism that encompasses the qualifications of the police officers for carrying out their tasks and effective utilization of means to reach goals. Improvisation typifies the escalated force model and consists in building unqualified policemen into protest policing and the incommensurable use of measures to perform their right and duties over a protest. The professional action is a hallmark of the negotiated management model. It is based on the employment of well-qualified policemen to police protest and the commensurable use of means to fulfill their public role. 
Indicators of the models of protest policing

\begin{tabular}{|l|l|l||}
\hline \multicolumn{1}{|l|}{$\begin{array}{r}\text { Models and their essential } \\
\text { features }\end{array}$} & \multicolumn{1}{|c|}{ Escalated force model } & \multicolumn{1}{|c|}{$\begin{array}{r}\text { Negotiated management } \\
\text { Indicators }\end{array}$} \\
\cline { 2 - 4 } $\begin{array}{l}\text { Intensity of physical violence used by } \\
\text { policemen to police protest }\end{array}$ & $\begin{array}{l}\text { Maximally high extent of the in- } \\
\text { tensity of physical violence }\end{array}$ & $\begin{array}{l}\text { Physical violence completely } \\
\text { avoided }\end{array}$ \\
\hline Legal legitimation of police behavior & $\begin{array}{l}\text { Police behavior is legally dele- } \\
\text { gitimate }\end{array}$ & $\begin{array}{l}\text { Police behavior is legally legiti- } \\
\text { mate }\end{array}$ \\
\hline $\begin{array}{l}\text { Social legitimation of police behavior } \\
\text { by protesters }\end{array}$ & $\begin{array}{l}\text { Police behavior is considered } \\
\text { repressive and unacceptable }\end{array}$ & $\begin{array}{l}\text { Police behavior is considered } \\
\text { non-coercive and acceptable }\end{array}$ \\
\hline Apprehension of protesters & All protesters arrested & None protester arrested \\
\hline Timing of police action & Reactive & Preventive \\
\hline Ability to make an agreement & $\begin{array}{l}\text { No ability to make an agree- } \\
\text { ment }\end{array}$ & $\begin{array}{l}\text { Performed ability to make an } \\
\text { agreement }\end{array}$ \\
\hline $\begin{array}{l}\text { Capacity to adjust to emerging situa- } \\
\text { tions }\end{array}$ & Rigidity & Flexibility \\
\hline $\begin{array}{l}\text { Predictability of police mode of con- } \\
\text { duct }\end{array}$ & Unpredictability & Predictability \\
\hline Professionalism of police officers & Improvisation & Professional action \\
\hline
\end{tabular}

Source: Own study.

The new theoretical framework for analyzing protest policing is the modified version of della Porta and Reiter's approach (1998, p. 4; 2006, p. 13). It consists of the following indicators: (i) intensity of physical violence used by policemen to police protest, (ii) legal legitimation of police behavior, (iii) social legitimation of police behavior by protesters, (iv) apprehension of protesters, (v) timing of police action, (vi) ability to make an agreement, (vii) capacity to adjust to emerging situations, (viii) predictability of police mode of conduct, and (ix) professionalism of police officers. The indicators take up the extreme values for the antinomic models of protest policing respectively. The essential features of the escalated force model are: maximally high extent of the intensity of physical violence, police behavior is legally delegitimate, police behavior is considered repressive and unacceptable, all protesters arrested, reactive timing of police action, no ability to make an agreement, rigidity in adjusting to emerging situation, unpredictability of police mode of conduct, and improvisation over protest policing. The distinguishing characteristics of the negotiated management model are: physical violence completely avoided, police behavior is legally legitimate, police behavior is considered non-coercive and acceptable, none protester arrested, preventive timing of police action, performed ability to make an agreement, flexibility in adjusting to emerging situations, predictability of police mode of conduct, and professional action during protest (Table 1).

\section{Slovenian Protest Policing: Between Escalated Force and Negotiated Management}

The new set of indicators allows us to examine the Slovenian model of protest policing in times of austerity. The first indicator is the intensity of physical violence used by policemen to police protest. In the analyzed period, 87 protests were attended by 52,000 people 
(each numbered from 50 to 15,000 people). At 2 protests, 31 participants were injured, which is 0.00059 percent of all the protesters. 115 police officers, 3 official horses were injured, 23 police vehicles and 18 facilities damaged (Policija, 2013). Policemen used 807 coercive measures against 330 people ( 0.00634 percent of the protesters), but the actual number of persons against whom the police used gas, cavalry, and water jets is higher. As the analysis shows, the intensity of the use of physical force was low. Nobody was killed and the number of wounded was short 0.01 percent (Policija, 2013). Police officers avoided starting violent clashes (Arbutina, glb, 2012). Therefore, the Slovenian case locates between the escalated force and negotiated management model close to the latter. However, the analysis reveals that the elements of the former were present in Slovenia.

The extent of legal legitimation of police behavior was very high because policemen acted within the bounds of the law established in Slovenia. Over the protests, the police detained persons on the basis of Article 43 of the Law on Police, Article 109 of the Minor Offenses Act, and Article 157 of the Criminal Procedure Act. They secured protest under the law by following the legislative acts: the Constitution of the Republic of Slovenia, European Convention for the Protection of Human Rights and Fundamental Freedoms, Law on Public Gatherings, Misdemeanors Act with amendments and supplements, Criminal Code, Criminal Procedure Act, Law on Police, The General Administrative Procedure Act, Law on the Protection of Public Order, The Law on Private Security, Weapons Act with amendments and supplements, Law on Civil Servants and bylaws: Rules for the implementation of the Law on Public Gatherings with amendments and supplements, Rules on Police Authorizations with amendments and supplements, Rules on providing legal assistance to police officers, Rules on the implementation of the Private Security Act, Rules on the direction and control of the police, Rules for the implementation of the Weapons Act, Decree on the compensation of salaries or lost earnings while performing certain duties of defense, on exercising the right to one-time financial assistance, and on the amounts of this assistance - with amendments, Decree on the method of using audio devices that cause noise and events at the gatherings and events, Regulation on compulsory organization of the security service at public events, and Decree on the protection of certain persons, premises, facilities, and neighborhoods of buildings protected by the police (Policija, 2013). In general, the police behavior complied with the acts they referred to. The Appeals Chamber recognized just 1 complaint against the police procedure founded (Policija, 2013). These arguments point out that the protest policing falls into the negotiated management model.

On the basis of Article 43 of the Law on Police that provides detention up to 24 hours, 183 from among 245 detained and arrested persons ( 74.7 percent) were detained up to 24 hours. However, police detained most of them (134 or 54.7 percent) up to 6 hours. On this legal basis, the minimum detention time was 35 minutes, and the longest was 14 hours and 20 minutes. In turn, on the grounds of Article 157 of the Criminal Procedure Act that provides for detention up to 48 hours, 42 protesters (69 percent) were detained for more than 42 hours. For 86.9 percent of persons, the detention was interrupted because there were no more reasons for its continuation. 31 persons ( 12.7 percent) were detained by the investigating judge (Policija, 2013).

When carrying out detentions, police officers respected the constitutionally guaranteed rights enjoyed by persons at the time of deprivation of liberty. The information on 
the duration of detention reveals that they respected the principle of proportionality and held persons only for an urgent time. According to the Specialized State Prosecutor's Office, 3 criminal charges were heard against police officers. 1 criminal complaint, filed against 1 police officer, was transferred to the Police Unit Maribor for consideration. 2 criminal charges were brought directly to the prosecutor's office. 1 criminal complaint was filed against 1 police officer and the other against a group of police officers (Policija, 2013).

As these arguments show, the extent of social legitimation of police behavior by participants of protest was very high. In contrast to other anti-austerity driven states, e.g. Spain (Lopez, 2012) and Ireland (Shea, 2015), the Slovenian police were not charged in the media with illegitimate behavior over protest policing (CBC News, 2012; Kirn, 2013a, 2013b; Santopadre, 2012). There were no complaints about the detention order, while 6 complaints were filed with the police procedure, 5 of which were considered by the Appeals Chamber and considered unfounded (Policija, 2013). Protesters considered police behavior non-coercive and almost fully acceptable apart from the uncommon exceptions, which was the manifestation of the negotiated management model.

For attacks on police officers, the police issued 21 criminal reports with 66 suspected persons, detained and arrested 245 protesters ( 0.00471 percent of all the participants). 4 out of these 245 protesters required and received medical assistance. All detainees were held only once over the analyzed period (Policija, 2013). The apprehension of protesters situates the Slovenian case between the escalated force and negotiated management models close to the latter because of the ratio of the detained and arrested to the protest attendees. The number of detained and arrested was short 0.01 percent.

Protesters registered only 6 out of 87 protests, which aggravated arrangements of protest policing (Policija, 2013). Although the timing of police action was reactive rather than pre-emptive, police endeavored to prevent fierce clashes. Hence, the reactiveness was rather subdued but it was an indication of the escalated force. It locates the Slovenian case between the escalated force and negotiated management models close to the former.

Despite a failure in reaching an understanding on the registering or informing about the timing of protests, the police established harmonious relations with protesters. Protest attendees helped the police find and identify the suspected of a crime, e.g., in the case of throwing a burning object at the Bank of Slovenia in Ljubljana (Policija, 2013). The police gave disposition and ability to pursue making an agreement with protest participants. No disagreement over the mode of protest policing occurred in Slovenia. So, the Slovenian case is between the escalated force and negotiated management models close to the latter.

The extent of police capacity to adjust to emerging situations was very high. Policemen did not make use of a single action form over and over again but employed a wide repertoire of action to control protest effectively. They made use of physical force (312 times), means of locking and tying (202 times), gas sprayer (119 times), baton (103 times), cavalry (1 time), and water jet (2 times) (Policija, 2013; RT, 2013). The police eschewed employing the hardest means over the bulk of protests but used cavalry and water jet to handle the most violent clashes. A very high extent of flexibility in selecting the least invasive means to secure protests effectively shows that 
the Slovenian case is between the escalated force and negotiated management models close to the latter.

The predictability of police mode of conduct was very high. Police officers held protesters for the following acts prohibited under penalty and defined by the Criminal Code: causing serious bodily injury (Article 123), damaging foreign objects (Article 220), preventing an official act or revenge on an official (Article 299), attack on an official when performing security duties (Article 300), participation in a group that prevents an official from officially acting (Article 301), and an attempt to prevent an official act or revenge on an official (Article 302) (Policija, 2013). Hence, protesters could anticipate the police responses to base motives on the grounds of previous police behavior and the upheld law. The Slovenian case is between the escalated force and negotiated management models close to the latter.

Protesters attacked the police by using physical force, fireworks, incendiary and improvised explosive objects, mass throwing of stones, granite cubes, banners, wooden and metal bars, traffic signs, metal garbage boxes, and other things found on the street. At the most massive protests, several hundred protesters threw dangerous items into the police at the same time. As a result, they physically injured many police officers, e.g., head and other parts of the body, caused stroke of the brain, loss of consciousness, cracking wounds, joints, and bone fractures. Aggressive protesters often continued to throw dangerous items while other police officers offered help to the injured and sometimes unconscious policemen (Policija, 2013; Mekina, 2012, 2014; Maza, 2013a, 2013b; Novak, Radosavljevic, Heinrich, 2012). Let us emphasize, the police had to cope with a very high extent of physical violence during protest policing.

The police were alert in times of protests and strived to detect preparatory actions. For instance, in the suburbs, a protester found a ready packing with flammable liquids. According to police informants, participants of the movement wanted to douse police officers with these fluids and then burn them (Policija, 2013). The police secured the packing and prevented a dangerous attack on them.

The extent of professionalism that encompasses the qualifications of police officers for carrying out the tasks and effective utilization of means to achieve goals was very high. Well-qualified policemen controlled protest and they used commensurable means to fulfill their public role. The police considerably increased expenses to protect life, personal safety, and property of people, prevent, discover, and inspect penal acts and minor offenses, discover and arrest those committing penal acts and minor offenses, maintain public order, perform tasks defined in the Law on Police and other laws and secondary legislation documents, just to mention the most important tasks (Ministry of the Interior Police, 2017). They used more material resources, such as regular work, as protests require a larger number of police officers engaged with specific equipment (Policija, 2013).

Importantly, there were no physical injuries in the use of coercive means since there were no consequences for 774 (95.9 percent) out of 807 used coercive measures. When using 30 coercive means, visible signs of their use were created (which according to the Criminal Code is not considered to be a personal injury), and the use of 3 coercive means (physical force) resulted in minor injuries (Policija, 2013). The police professionalism, assessed on the basis of the qualifications of the police officers for carrying out their 
tasks and effective utilization of means to attain goals, indicates that the Slovenian case is between the escalated force and negotiated management models close to the latter.

The analysis demonstrates that the negotiated management model with the elements of the escalated force occurred in the austerity-driven Slovenia. On the one hand, the police did not abandon using physical violence to police protests, which is a feature of the escalated force type. On the other, the extent of its intensity was low. Another characteristic of the violent model that characterizes the Slovenian case is reactiveness in the timing of police action. It might have stemmed from the character of relations with the movement that evaded registering its public gatherings. The remaining components of protest policing identified in Slovenia are typical of the negotiated management type. Police behavior was legally legitimate because officers acted within the bounds of the law established in Slovenia. In addition, the extent of social legitimation of police behavior by participants of protest was very high. Protesters considered police behavior noncoercive and almost fully acceptable apart from the uncommon exceptions. The ratio of the detained and arrested to the protest attendees was short 0.01 percent, which reveals a very small number of apprehension of protesters. The police performed the ability to make an agreement with participants of protests. They proved flexible by adjusting to emerging situations. The predictability of police mode of conduct was very high because protesters could anticipate police responses to base motives on the grounds of previous police behavior and the upheld law. The extent of professionalism that embraces the qualifications of police officers for carrying out the tasks and effective utilization of means to reach objectives was very high. The skilled policemen controlled protest and they used commensurable means to fulfill their public role.

\section{Conclusions}

The new theoretical framework is found to be an analytically effective tool. It allowed us to determine that the Slovenian model of protest policing is between the antinomic ideal types of escalated force and negotiated management close to the latter. This model has 7, out of 9, strong essential features of the negotiated management model. Nevertheless, it has also 2 weak elements of the escalated force model: the use of physical violence by policemen to police protests and timing of police action. This peaceful mode of protest policing derived from the organizational dynamics of the Slovenian National Police (Policija, 2013). The research confirmed the theory that if the police follow the dialectic of decentralization and hierarchical submission in police units, the negotiated management model emerges. Indeed, the police acted at local, general, and regional levels. In each of 8 police units under Regional Police Directorates and, controlled by them, 111 police stations subordinated to the Director General of the Police, police officers of the Special Police Unit, other policemen, criminals, and technical staff were deployed.

Furthermore, as the research verifies, the negotiated management model develops when the police effectively use possibilities to coordinate the different groups operating within protesting crowds. The Slovenian National Police extended the number of material resources for protest policing and successfully took advantage of them. They involved the variety of means and coercive measures to deal with the various types of 
protesters in compliance with the individual policing needs. Noteworthy, they contrived to minimize the risk of damage over the implementation of the coercive measures.

Finally, the analysis validates the statement that the police certainty about the aims of the intervention results in the appearance of the negotiated management model. The police expressed their goals openly (Ministry of the Interior Police, 2017). They primarily sought to protect life, personal safety, and property, prevent, discover, and inspect penal acts and minor offenses, discover and arrest those committing penal acts and minor offenses, maintain public order, and perform tasks defined in the Law on Police and other laws and secondary legislation documents.

\section{Bibliography}

Arbutina Z., glb (2012), Slovenia - back to reality, forth to austerity, 17.12.2012, "DW", http://www. dw.com/en/slovenia-back-to-reality-forth-to-austerity/a-16459181, 10.02.2018.

CBC News (2012), Anti-austerity Slovenia protesters clash with police: Has worst recession of 17 eurozone countries, 01.12.2012, “CBC News", http://www.cbc.ca/news/world/anti-austerity-slovenia-protesters-clash-with-police-1.1298756, 10.02.2018.

della Porta D., Reiter H. (1998), The Policing of Protest in Western Democracies, in: Policing Protest: The Control of Mass Demonstrations in Western Democracies, eds. D. della Porta, H. Reiter, University of Minnesota Press, Minneapolis, London.

della Porta D., Reiter H. (2006), The Policing of Global Protest: The G8 at Genoa and its Aftermath, in: The Policing of Transnational Protest, eds. D. della Porta, A. Peterson, H. Reiter, Ashgate Publishing Limited, Hampshire-Burlington.

Durić D., Žibret D. (2017), Respond to query 630-36/2017/4: Slovenian National Police. Register: $630-36 / 2017 / 4(262-03)$ [in the author's records].

Finlay Ch. J. (2017), The concept of violence in international theory: a Double-Intent Account, "International Theory", vol. 9, no. 1.

Flesher Fominaya C. (2017), European anti-austerity and pro-democracy protests in the wake of the global financial crisis, "Social Movement Studies", vol. 16, no. 1.

Kirn G. (2013a), A ghost is haunting Slovenia, the ghost of revolution!, 16.02.2013, "New Socialist", http://www.newsocialist.org/679-a-ghost-is-haunting-slovenia-the-ghost-of-revolution, 10.02.2018.

Kirn G. (2013b), Social Uprising in Slovenia against Neoliberal Austerity Measures, 25.02.2013, "Global Research", http://www.globalresearch.ca/social-uprising-in-slovenia-against-neoliberal-austerity-measures/5324218, 10.02.2018.

Krašovec P. (2013), The Slovenian Uprising in Retrospect, "Debatte: Journal of Contemporary Central and Eastern Europe", vol. 21, no. 2-3.

Lopez A. (2012), Spain's anti-cuts Protests Violently Broken up by Police, 27.09.2012, "World Socialist Website", http://projectcensored.org/riot-police-violently-break-up-anti-austerity-protestsin-spain/, 10.02.2018.

Maza C. (2013a), Rough guide to Slovenian protests, 2012/2013, 04.02.2013, “Cafebabel”, http://www. cafebabel.co.uk/society/article/rough-guide-to-slovenian-protests-20122013.html, 10.02.2018.

Maza C. (2013b), Slovenia Joins Euro Zone Anti-Austerity Protests, 10.02.2013, "Policy.Mic", https:// mic.com/articles/25332/slovenia-joins-euro-zone-anti-austerity-protests\#.bVS7ZwHT0, 10.02.2018.

Mekina B. (2012), Slovenia: The placid people's revolt, 14.12.2012, "Vox Europ”, http://www.voxeurop.eu/en/content/article/3163301-placid-people-s-revolt, 10.02.2018. 
Mekina B. (2014), EU elections to test Slovenia's handling of crisis, 26.02.2014, "Euobserver", https:// euobserver.com/eu-elections/123150, 10.02.2018.

Millen F., Stephens M. (2011), Policing and accountability: the working of police authorities, "Policing and Society", vol. 21, no. 3.

Ministry of the Interior Police (2017), Task and Goals, https://www.policija.si/eng/index.php/aboutthepolice/tasksandgoals.

Novak M., Radosavljevic Z., Heinrich M. (2012), Slovenia police arrest 141 in violent anti-austerity protests, 04.12.2012, "Reuters", http://www.reuters.com/article/us-slovenia-arrestsidUSBRE8B30QM20121204, 10.02.2018.

Perković A. J., Učakar T. (2017), Economic crisis and the crisis of national identity in Slovenia: toward a new notion of social order, "Nationalities Papers: The Journal of Nationalism and Ethnicity", vol. 45 , no. 2 .

Policija (2013), Analiza aktivnosti policije ob protestih na območju Republike Slovenije [in the author's records].

Punch K. F. (2014), Introduction to Social Research: Quantitative and Qualitative Approaches, 3rd edition, Sage, London.

Rak J. (2017), Intrastate, Regional, and Colonial Contributions to Post-2008 Cultures of Political Violence, "Polish Political Science Yearbook", vol. 46, no. 1.

Rak J. (2018a), From Mobilization to Demobilization: Dynamics of Contention in the Austerity-driven Slovenia, "Środkowoeuropejskie Studia Polityczne", vol. 3.

Rak J. (2018b), Theorizing Cultures of Political Violence in Times of Austerity: Studying Social Movements in Comparative Perspective, Routledge, London-New York.

Razsa M., Kurnik A. (2012), The Occupy Movement in Žižek's hometown: Direct democracy and a politics of becoming, "American Ethnologist", vol. 39, no. 2.

RT (2013), Anti-austerity protests rock Slovenia as fears of bailout grow, 27.04.2013, "RT”, https:// www.rt.com/news/austerity-protests-bail-out-504/, 10.02.2018.

Santopadre M. (2012), Slovenia: proteste antiausterity e scontri a Maribor e Lubiana, 02.12.2012, "Contropiano", http://contropiano.org/news/internazionale-news/2012/12/01/slovenia-proteste-antiausterity-e-scontri-a-maribor-e-lubiana-012989, 10.02.2018.

Shea J. O. (2015), The Criminalisation of Social Protest in the Republic of Ireland: The Movement against Economic Austerity and Water Privatization. The Jobstown Aftermath and the ECHR, 27.02.2015, "Global Research”, February 27, http://www.globalresearch.ca/the-criminalisation-of-social-protest-in-the-republic-of-ireland-the-movement-against-economic-austerityand-water-privatization/5433673, 10.02.2018.

Tilly Ch. (2006), Regimes and Repertoires, The University of Chicago Press, Chicago-London.

Toplišek A., Thomassen L. (2017), From Protest to Party: Horizontality and Verticality on the Slovenian Left, "Europe-Asia Studies", vol. 69, no. 9.

Wada T. (2016), Rigidity and Flexibility of Repertoires of Contention, "Mobilization: An International Quarterly", vol. 21, no. 4.

Whelan Ch. (2017), Security networks and occupational culture: understanding culture within and between organisations, "Policing and Society", vol. 27, no. 2.

\section{Polityka kontroli protestu w Słowenii w okresie wychodzenia z kryzysu ekonomicznego}

\section{Streszczenie}

Celem artykułu jest ocena polityki kontroli protestu w Słowenii w okresie wychodzenia z kryzysu ekonomicznego oraz weryfikacja analitycznej efektywności narzędzia do pomiaru kontroli protestu. 
Tekst prezentuje krytyczną dyskusję nad modelem teoretycznym składającym się z antynomicznych typów idealnych eskalowanej siły i negocjowanego kierowania autorstwa Donatelli della Porty i Herberta Reitera. Następnie, wykorzystuje je w roli narzędzia do zanalizowania słoweńskiego przypadku. W badaniu zastosowano jakościową metodę analizy źródeł opartą na konceptualnej jakościowej analizie zawartości, żeby rozwiązać następujące problemy badawcze: jaki model kontroli protestu wystąpił w Słowenii w okresie implementacji polityki surowości? I dlaczego kontrola przybrała taką formę? Studium pokazuje, że w Słowenii pojawił się model negocjowanego kierowania z elementami eskalowanej siły. Ten typ kontroli protestu wynikał z organizacyjnej dynamiki Słoweńskiej Policji Narodowej, która odznacza się dialektyką decentralizacji i hierarchicznego podporządkowania w oddziałach policji, efektywnym wykorzystywaniem możliwości koordynacji różnych grup działających w obrębie protestujących tłumów oraz pewnością co do celów interwencji.

Słowa kluczowe: polityka kontroli protestu, kultura przemocy politycznej, Słoweńska Policja Narodowa, ruch protestu, demonstracja polityczna 
